\title{
Assessing the Guidelines for Pre-Harvest Clearing Operations of Understory in First Thinnings: Preliminary Results from Stora Enso in Finland*
}

\author{
Kalle Kärhä ${ }^{1^{* *}}(\mathbb{D})$, Dan Bergström ${ }^{2}$ \\ ${ }^{1}$ Stora Enso, Wood Supply Finland, P.O. Box 309, FI-00101 Helsinki, Finland \\ ${ }^{2}$ Swedish University of Agricultural Sciences, Department of Forest Biomaterials and Technology, SE-90183 \\ Umeå, Sweden
}

\begin{abstract}
The objective of this study was to analyze forest industry professionals' opinions of the utility of pre-clearance work prior to the first-thinning operations. A total of 153 interviews were conducted with three groups of professionals (forest machine entrepreneurs, harvester operators and logging officers) with a response rate of $80 \%$. In general, the respondents agreed that the occurrence of understory would hinder the cutting work if the softwood tree understory density exceeded 1,152 trees/ha and a height of $1.42 \mathrm{~m}$. The corresponding values for broadleaved trees were 1,669 trees/ha and a height of $1.86 \mathrm{~m}$. The respondents stated that trees eligible for logging should be pre-cleared within a circular area with a mean radius of $1.24 \mathrm{~m}$, and the stump height of cleared trees should not exceed $10.8 \mathrm{~cm}$. In intermediate areas (i.e., outside of the circular areas) understory trees exceeding a height of $1.96 \mathrm{~m}$ should be pre-cleared. Pre-harvest clearing should be conducted, on average, 9.2 months prior to the logging operation. The results indicated significant differences between the opinions of the respondents concerning the understory density, the height that would hinder cutting and the most convenient pre-harvest clearing method. As a result of this research, pre-clearance guidelines, based on the best-practice knowledge of the professionals, was launched at Stora Enso company in Finland. Because the study results were based on subjective knowledge, they should be validated by long-term empirical data collection and continuing analysis of the effect of understory trees on the efficiency of a forest machine operator.
\end{abstract}

Keywords: Undergrowth, Pre-clearance, Logging, Cutting, Interview survey

\section{Introduction}

Finland's National Forest Strategy 2025 has set a goal of increasing the amount of total annual roundwood removals from around 65 million $\mathrm{m}^{3}$ solid over the bark (henceforth referred to as $\mathrm{m}^{3}$ ) in 2013 to 80 million $\mathrm{m}^{3}$ by 2025 (Ministry of Agriculture and Forestry, 2015). In 2018 , total roundwood removal reached 78.2 million $\mathrm{m}^{3}$ in Finland, harvested over a total area of 747,000 ha (first thinnings 152,500 ha, later thinnings 390,500 ha and a final felling of 204,600 ha) (Natural Resources Institute Finland, 2019a; 2019b).

Annually, around 7-8 million $\mathrm{m}^{3}$ of first-thinning wood is harvested in Finland (cf., Kärhä and Keskinen, 2011). Nevertheless, according to Korhonen et al. (2017), the annual first-thinning area is double that in Finland (i.e., more than 350,000 ha/year). If, for instance, $300,000 \mathrm{ha} /$ year of first thinnings would be harvested, annual loggings of approximately $11-13$ million $\mathrm{m}^{3}$ of wood could be possible.

The reason for the lack of interest in performing first thinnings can be explained by the fact that they generate high logging costs per $\mathrm{m}^{3}$ harvested, particularly for cutting, which in turn is due to the logging of small stem sizes which gives low wood removals per ha and per logging site. In addition, the prevalence of sightobstructing, dense understory vegetation slows down the cutting work (e.g., Kärhä et al., 2004; Kärhä, 2006; Kärhä and Keskinen, 2011). On average, the firstthinning logging costs carried out in Finnish forests were $€ 16.8 / \mathrm{m}^{3}$, when the average stem size of removal in the stand was $0.084 \mathrm{~m}^{3}$ and the average industrial roundwood removal was $52 \mathrm{~m}^{3} / \mathrm{ha}$; while the corresponding figures for later thinnings and final fellings were $€ 13.7 / \mathrm{m}^{3}, 0.145 \mathrm{~m}^{3}$ and $63 \mathrm{~m}^{3} / \mathrm{ha}$, and $€ 8.1 / \mathrm{m}^{3}, 0.350 \mathrm{~m}^{3}, 194 \mathrm{~m}^{3} / \mathrm{ha}$, respectively (Strandström, 2018a; 2018b).

In order to reach the target harvested industrial roundwood volumes in 2025 , the logging cost per $\mathrm{m}^{3}$ must be decreased. There are several ways that this can be achieved. Firstly, the timing of the tending of the seedling stands is important, and must be performed 
vigorously enough so that the crop trees will have a high probability of reaching the desired roundwood dimensions by the first-thinning operation, thus generating the larger stem size of removal in the stand and further higher extractible volume per ha. Secondly, the cutting work conditions at the point of first thinning can be improved by pre-harvest clearing of the dense understory vegetation that is sight-obstructing during the cutting work. Wood procurement professionals considered the pre-harvest clearing of the understory to be the most important measure for increasing the effectiveness of the first thinnings (Oikari et al., 2010). Haavikko et al. (2019) reported that forest machine entrepreneurs considered sight-obstructing understory vegetation to be one of the most meaningful factors affecting energy efficiency in logging work.

The field guidelines for performing pre-harvest clearing work, published at the beginning of the 2000s in Finland (Hakkuutyömaan ennakkoraivaus, 2001), underline the fact that substantial understory vegetation hinders the visibility of a harvester operator when selecting the stems to be cut. Additionally, understory trees might get stuck in the harvester head causing saw chain to break or get stacked and causing hydraulic hoses to break, as well as preventing the operator to positioning the harvester head correctly in order for the stem to be cut. To sum up, the guidelines for pre-harvest clearing (Hakkuutyömaan ennakkoraivaus, 2001) emphasize that these factors decrease the cutting work efficiency and the quality of logging operations.

During the last 15 years, several time studies on cutting and forwarding productivity and costs, and logging quality in first-thinning stands with and without understory vegetation, have been conducted (e.g., Frank, 2006; Kärhä et al., 2006; Kärhä, 2006; Thunell, 2008; Dehlén, 2010; Eriksson and Lindberg, 2010; Niemistö et al., 2012; Pålsson, 2013; Jonsson, 2015; Bergström et al., 2016; Hjelmqvist, 2016; Sjöqvist and Olofsson, 2018; Skogelid, 2019). These studies do not show any clear correlation between cutting work efficiency and the density of understory vegetation, except that the dense understory of Norway spruce (Picea abies (L.) Karst.) can significantly limit visibility. In contrast, there are only a few studies in which the opinions of forest industry professionals on the impact of understory trees on operator work have been analyzed (cf., Heikkinen, 2012; Lankinen, 2012; Sanz et al., 2019).

In the early 2000s, the annual pre-harvest clearing areas in intermediate thinnings in Finland was approximately 30,000 ha and amounted to 73,400 ha in 2018 (Natural Resources Institute Finland, 2019c). Approximately a half of the pre-cleared areas conducted in 2018 were judged to have fulfilled the criteria of acceptance according to the guidelines (Finnish Forest Centre, 2019). Correspondingly, the Finnish Forest Centre gauged that at every tenth thinning stand, the pre- harvest clearing had either not been conducted at all, even if it should have been done, or it had been conducted very poorly. The current national pre-harvest clearing guidelines of understory for first-thinning stands in Finland are set out below (Äijälä et al., 2019).

- Clear the understory within a circular area with a radius of approximately 1 meter around each merchantable stem.

- Clear any understory vegetation, particularly Norway spruce understory over two meters high which may hinder the visibility of the harvester operator, from the intermediate areas of the logging site.

- Inside the circular areas, saw the understory trees into short stumps and fell them away from the butts of the pre-cleared stems.

- If the Norway spruce understory tree vegetation is viable, and it is a target to grow further it, only the spruce understory trees in the circular areas of the merchantable stems should be pre-cleared.

- Pre-clearance must be conducted in advance, preferably one to three years before logging, in order to allow the cleared understory vegetation to return to the ground.

- Pre-harvest clearing should not be conducted in economically low-yielding areas, such as wet depression areas, transition zones and rocky areas.

- European aspen (Populus tremula L.), goat willow (Salix caprea L.), black alder (Alnus glutinosa Gaertn.), pedunculate oak (Quercus robur L.), smallleaved lime (Tilia cordata Mill.), elm (Ulmus spp.), Norway maple (Acer platanoides L.), European ash (Fraxinus excelsior L.) and European walnut (Juglans regia L.), as well as the buffer zones of small water areas can be left untreated during pre-clearance.

- Finally, it is essential to preserve understory vegetation that provides protection for wildlife, particularly for wild birds.

The objective of this study was to clarify the forest industry professionals' opinions regarding the utility of pre-clearance work prior to first-thinning operations. The practical implementation of this work was to construct new pre-harvest clearing guidelines that could be used at Stora Enso Wood Supply Finland (WSF).

\section{Material and Methods \\ 2.1. Interviews}

The survey was conducted by phone interviews. Three parties of the wood supply chain took part in the survey: forest machine entrepreneurs, harvester operators and logging officers. Of all the forest machine entrepreneurs $(\mathrm{N}=43)$ that were contracted to WSF, 41 responded to the survey. During the interviews, every entrepreneur was asked to name their two machine operators that had the most experience regarding firstthinning harvester work. In total 75 operators out of 88 were interviewed. 
Out of the 54 logging operation superintendents at Stora Enso WSF, 49 were interviewed. Out of these 49 interviews, 18 were rejected as the respondents had a very poor working knowledge of pre-harvest clearing work and first-thinning stand conditions in practice. All of the entrepreneur superintendents at WSF $(\mathrm{N}=6)$ were interviewed in the survey. In total, 37 logging officers' interviews were used in the analysis.

The survey material consisted of a total of 153 interviews, and the response rate was $80.1 \%$. Almost a half $(49.0 \%)$ of the respondents were harvester operators, more than one-quarter $(26.8 \%)$ were forest machine entrepreneurs, while the rest $(24.2 \%)$ were logging officers.

\subsection{Questionnaire}

A structured questionnaire was drawn up, which consisted of three sections. In the first section, the harvester operators' experience with thinning work and the cut volumes made during the last 12 months were ascertained. On average, the harvester operators had 12.3 years' experience of first-thinning cutting work. One year prior to the interview, they had cut, on average, $11,089 \mathrm{~m}^{3}$ /operator, ranging from 1,650 to $33,000 \mathrm{~m}^{3}$.

The second and third sections of the questionnaire were similar for all the survey groups. In the second section, the respondents were asked what a hindering understory is. In other words, what are the pre-harvest clearing limits when pre-harvest clearing must be conducted from the point of view of the respondents, if the understory vegetation mostly consists of softwood trees (e.g., Norway spruce and Scots pine (Pinus sylvestris L.)), broadleaved trees (mainly birch (Betula spp. L.), willow (Salix spp.), alder (Alnus spp.), aspen, and European mountain ash (Sorbus aucuparia L.)) or mixed softwood and broadleaved trees?

The third part of the questionnaire concerned the characteristics of acceptable pre-harvest clearing work:

1) Clearing around of the butts of merchantable stems:

- What is the radius (m) of the circular area around the trees' butt to be harvested that must be precleared?

- What should the maximum stump height $(\mathrm{cm})$ of pre-cleared trees be?

2) Clearing the intermediate areas (i.e., the areas outside of circular areas on the logging site):

- Is total (i.e., all understory is pre-cleared) or selective pre-harvest clearing (i.e., only hindering understory is pre-cleared) more desirable for intermediate areas?

- When selective pre-harvest clearing is used, what kind of understory trees (e.g., trees of a certain height) must be pre-cleared from intermediate areas?
3) Timing of pre-clearance:

- How much earlier, in months, should the preharvest clearing work be conducted before cutting?

\subsection{Data Analysis}

The variables related to understory vegetation and pre-clearance in the study were analyzed using percentage shares and distributions, mean values and standard deviations (std). The study data was initially tested for normal distribution assumption by a Kolmogorov-Smirnov test. Based on the results of the test, the study data did not comply with normal distribution. Since the material was not distributed normally, non-parametrical tests such as the MannWhitney test (U) and the Kruskal-Wallis one-way ANOVA test $\left(\chi^{2}\right)$ were used in the statistical analysis of the study. A $p$-value of 0.05 was applied for significance, and all statistical analyses of the data were conducted using IBM SPSS Statistics 26 software.

\section{Results and Discussion}

\subsection{Pre-Harvest Clearing Limits}

On average, the interviewees considered that understory vegetation will negatively affect the efficiency of the cutting work when:

- The softwood tree understory density is $>1,152$ trees/ha and the height $>1.42 \mathrm{~m}$;

- The broadleaved tree understory density is $>1,669$ trees/ha and the height $>1.86 \mathrm{~m}$; and

- The mixed softwood and broadleaved tree understory density is $>1,353$ trees/ha and the height $>1.62 \mathrm{~m}$ (Figures 1 and 2).

The results also revealed that the understory density and height limits that would hinder cutting mentioned by the harvester operators and forest machine entrepreneurs were similar to each other and were significantly lower than the estimations given by the logging officers (Figures 1 and 2, Table 1). The entrepreneurs and operators stated that softwood tree understory vegetation becomes a hindrance when the mean density exceeds 1,000 trees/ha and the mean height exceeds $1.3-1.4 \mathrm{~m}$. The corresponding values for broadleaved trees were slightly higher - the mean density exceeding 1,3001,500 trees/ha and the mean height exceeding $1.8 \mathrm{~m}$.

The logging officers regarded densities of softwood understory trees exceeding 2,100 trees/ha and 3,700 trees/ha for broadleaved trees as hindering cutting work. Moreover, the logging officers judged that softwood tree understory vegetation above $1.7 \mathrm{~m}$ in height and broadleaved tree understory above $2.2 \mathrm{~m}$ in height is hindering the cutting work (Figures 1 and 2). 


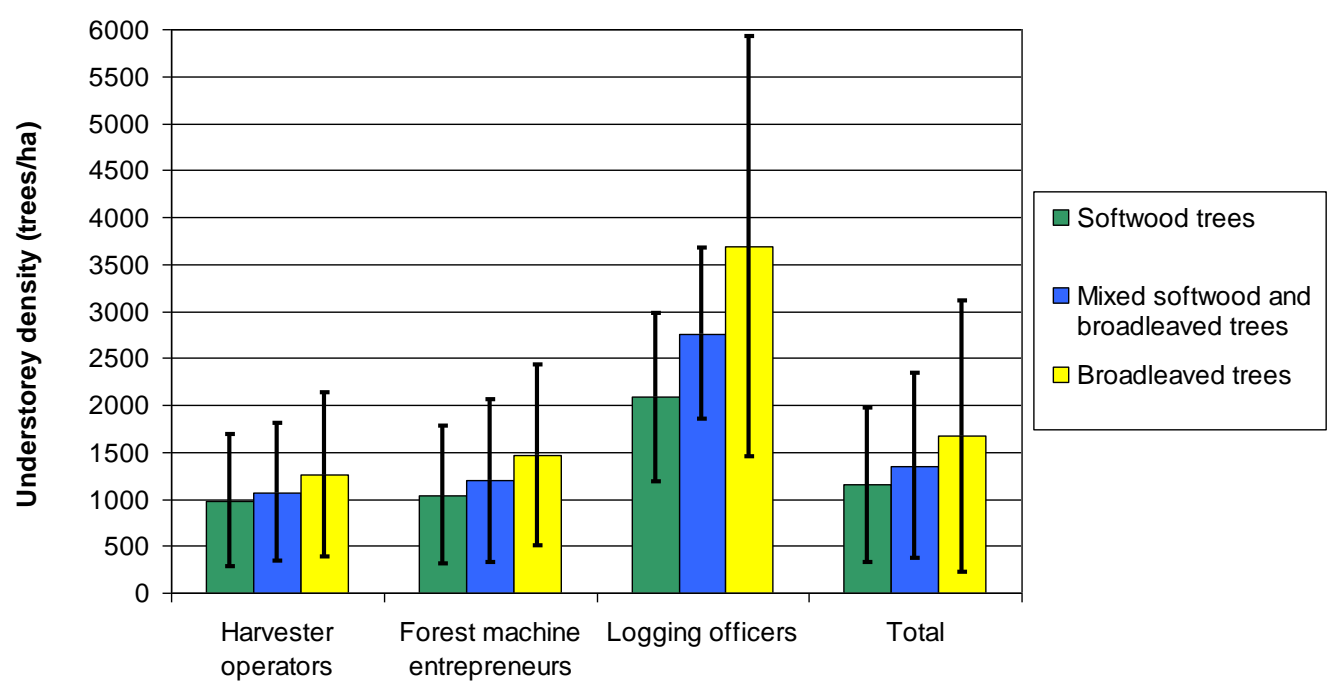

Figure 1. Respondents' opinions on thresholds for when understory tree density begins to hinder the cutting work in firstthinning stands (Bars = Average values; Black lines $=$ Standard deviation)

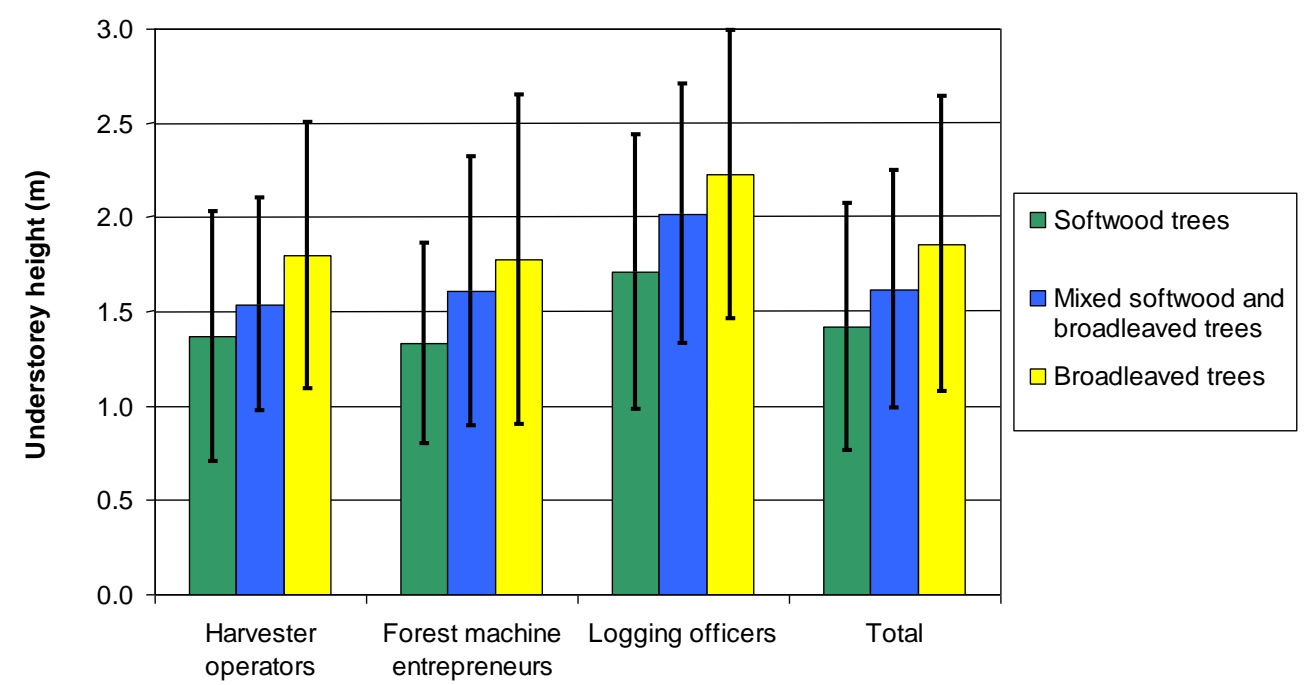

Figure 2. Respondents' opinions on thresholds for when understory height begins to hinder the cutting work in first-thinning stands

Table 1. Results from the Kruskal-Wallis tests of studied variables

\begin{tabular}{lcc}
\hline Type of understory & Kruskal-Wallis Test Value $\left(\chi^{2}\right)$ & Significance Level \\
\hline Understory density & & $* * *$ \\
Softwood trees & 25.97 & $* * *$ \\
Broadleaved trees & 30.71 & $* * *$ \\
Mixed softwood and broadleaved trees & 31.54 & 0.072 \\
\hline Understory height & & $*$ \\
Softwood trees & 5.27 & $*$ \\
Broadleaved trees & 6.86 & \\
Mixed softwood and broadleaved trees & 6.98 & \\
\hline Significance levels: ${ }^{*} p<0.05,{ }^{* *} p<0.01,{ }^{* *} p<0.001$ & &
\end{tabular}

\subsection{Characteristics of Good Pre-Harvest Clearing}

The respondents stated that for the trees eligible for logging, a circular area with a mean radius of $1.24 \mathrm{~m}$ should be pre-cleared and the remaining stumps of understory trees should not exceed $10.8 \mathrm{~cm}$ (Figures 3 and 4). If we assume that the first-thinning stand had 1,700 trees/ha eligible for logging, all the trees were evenly spread in the stand, and the circular areas (the radius of $1.24 \mathrm{~m}$ ) are pre-cleared around each harvestable stem, our analysis shows that approximately $80 \%$ of the total stand area will be pre-cleared. As a comparison, if the pre-harvest clearing radius was instead $1.0 \mathrm{~m}$, approximately $50 \%$ of the corresponding area would be pre-cleared.

There were no statistically significant differences between the respondent groups' opinions on the preharvest clearing radius length and the stump height of the pre-cleared understory trees (radius of circular area: $\chi^{2}=$ $1.73 ; p=0.422$ and stump height: $\chi^{2}=1.36 ; p=0.506$ ). 


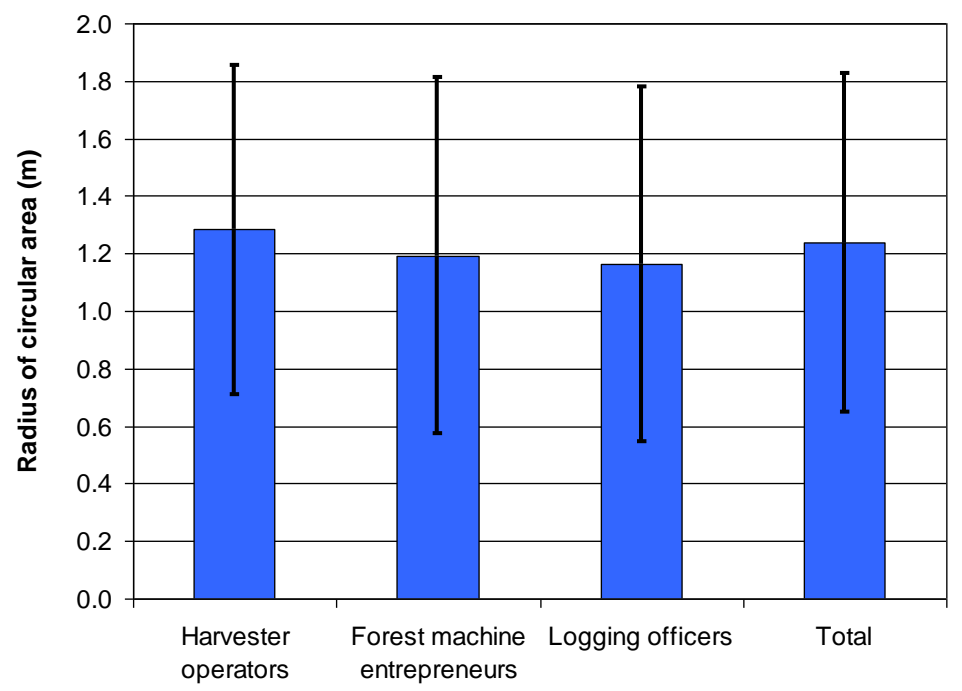

Figure 3. Respondents' opinions on how large the circular area around the butts of trees eligible for logging must be in the preharvest clearing of first-thinning stands

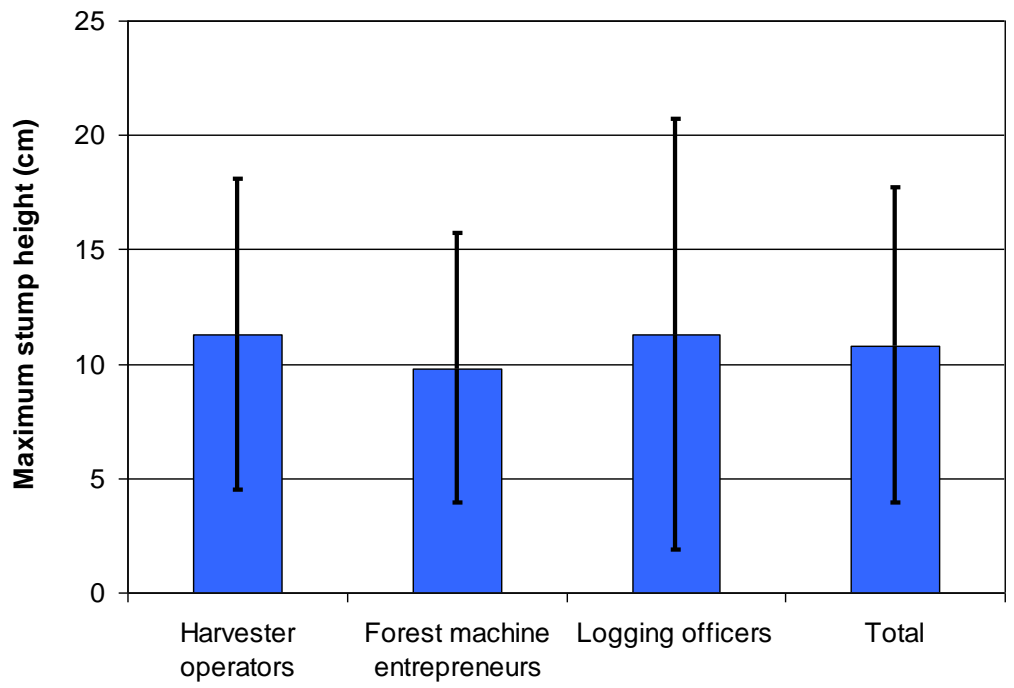

Figure 4. Respondents' opinions on what the maximum stump height sawn in the circular area around the butts of trees eligible for logging in first-thinning stands should be

In intermediate areas, understory vegetation exceeding, on average, $1.96 \mathrm{~m}$ (std: $0.69 \mathrm{~m}$ ) should be pre-cleared, and there was no statistically significant difference between the respondent groups' opinions in this regard $\left(\chi^{2}=0.15 ; p=0.699\right)$. Close to $90 \%$ of the harvester operators and almost $65 \%$ of the forest machine entrepreneurs stated that total pre-harvest clearing would be the most convenient pre-harvest clearing method for the intermediate areas (Figure 5).

The operators and entrepreneurs explained in the interviews that the time taken for pre-harvest clearing work increases when a brush saw worker has to go out and weave in the dense understory vegetation with their brush saw to clear only the tall $(>2 \mathrm{~m})$ understory trees from the intermediate areas. Correspondingly, the logging officers strongly stressed that the selective preharvest clearing, which means that the understory $<2 \mathrm{~m}$ tall should be left uncleared, is the most suitable preharvest clearing method for the intermediate areas of first thinnings. There was a statistically significant difference between the three respondent groups' opinions on the most desirable pre-harvest clearing method (total vs. selective) $\left(\chi^{2}=44.65 ; p<0.001\right)$ in the study.

Pre-clearance should be conducted, on average, 9.2 months prior to logging, thus enabling the cut understory to be well compressed on to the ground (Figure 6). However, many operators and entrepreneurs stressed that it is more important that the pre-harvest clearing is done prior to logging, rather than ensuring it is done a predetermined number of months beforehand. The logging officers, on the other hand, emphasized that preharvest clearing has to be done, on average, 12.6 months before logging. Because of the large variation in the answers by the respondent groups interviewed (Figure 6), there was no statistically significant difference between the respondent groups' opinions on the timing of understory pre-clearance $\left(\chi^{2}=1.56 ; p=0.458\right)$. 


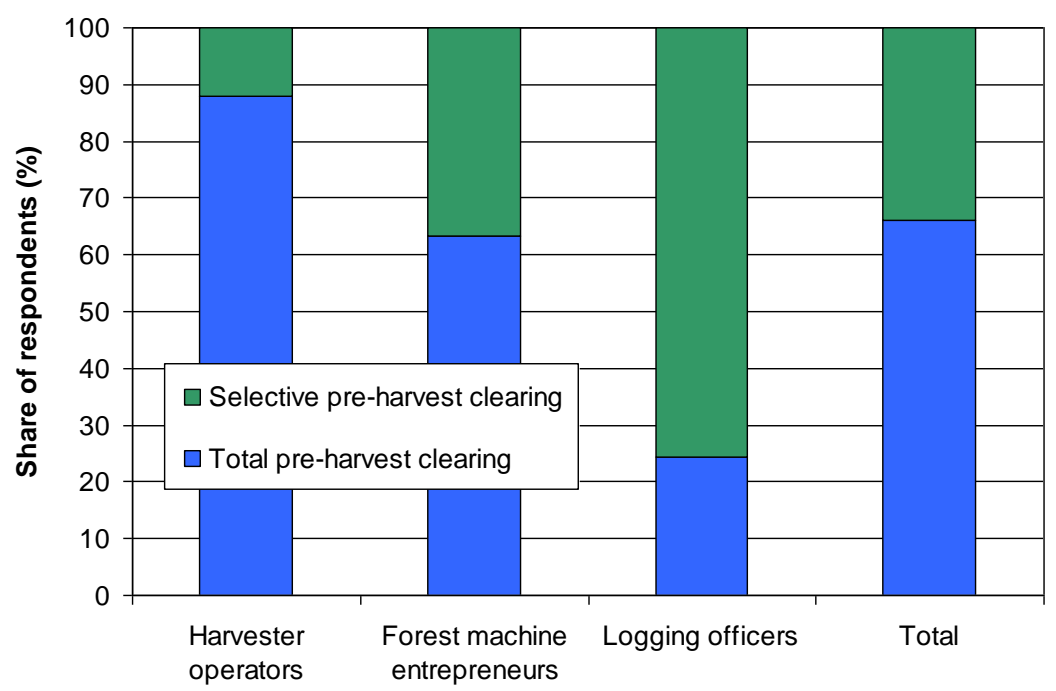

Figure 5. Respondents' opinions on what is the most desirable pre-harvest clearing method on the intermediate areas of firstthinning stands (total pre-harvest clearing means that all understorey trees are pre-cleared, and selective pre-harvest clearing means that in intermediate areas, only tall (>2 m) understorey trees are pre-cleared)

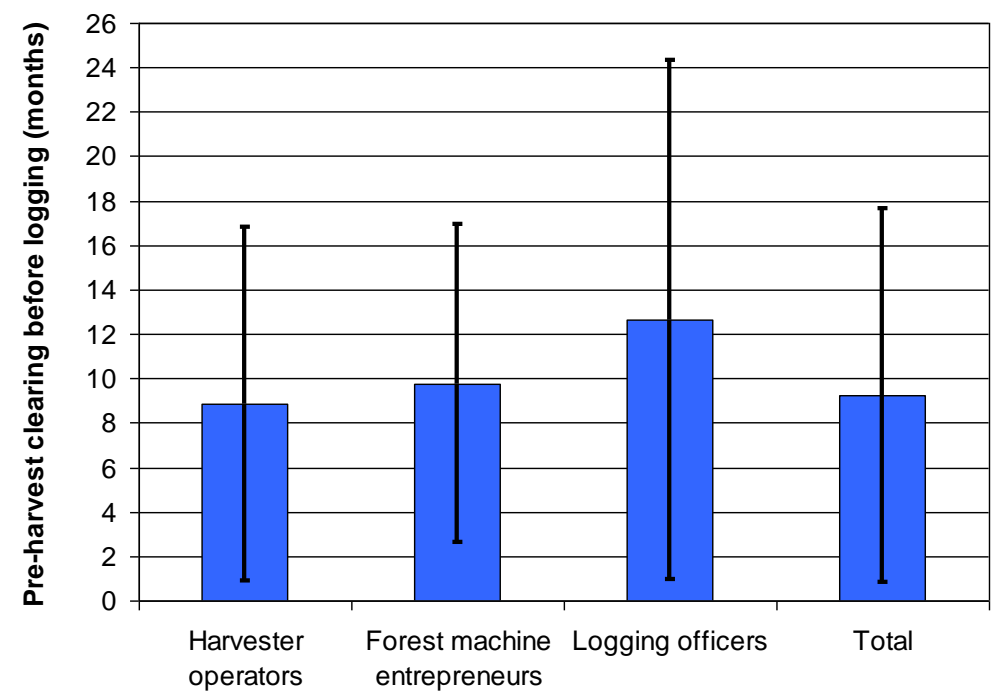

Figure 6. Respondents' opinions on how much earlier pre-harvest clearing has to be done prior to logging operations in firstthinning stands

3.3. Practical Implementation of Results and the Construction of the Novel Pre-Harvest Clearing Guidelines

This study aimed to survey the practitioners' opinions and to compile results enabling them to construct guidelines for pre-harvest clearing work in first-thinning stands at Stora Enso WSF. The study provided a good understanding of the opinions of the respondent groups related to the levels of the understorey (type, density and height) limits that have a negative impact on logging efficiency. The study showed significant differences in the opinions of the groups of forest industry professionals concerning the understorey density and height that can hinder cutting and the most convenient pre-harvesting clearing method.

An interesting discovery made by this study was that the understorey density and height limits hindering the cutting mentioned by the harvester operators and forest machine entrepreneurs were very similar to each other and were significantly lower than the estimations mentioned by the logging officers in the study (cf., Figures 1 and 2). Moreover, the harvester operators and forest machine entrepreneurs preferred more total preclearance than the selective pre-harvest clearing operation, which the logging officers regarded as the most desirable pre-harvest clearing method (cf., Figure 5). These differences are probably because the operators and entrepreneurs prefer as easy and visually clear harvesting conditions as possible and are not considering the costs of the pre-clearance operation. Meanwhile the logging officers concern these costs and thus aim to avoid any unnecessary clearing work (i.e., total preclearance) on the logging sites.

Nonetheless, we have to realize that the set limits were based on the conceptions and experiences of the interviewees, and that the views of the harvester operators, being experienced first-thinning operators and having cut huge volumes of timber on first thinnings during the last 12 months, can be considered to be of greater importance when judging possible impacts on the 
work. The differences between forest machine operators illustrate that these issues are encountered individually, and as Kärhä (2006) shows, different harvester operators have different tolerance thresholds towards the impact of the understorey on work efficiency. In addition, the results revealed great variations in the views of the other respondent groups (i.e., entrepreneurs and logging officers) in the study (cf., Figures 1-6).

The results should not, however, be used as actual pre-harvest clearing limits due to the fact that the following factors influencing logging cost have not been included: 1) the declining cutting and forest haulage productivity caused by understorey, and its additional cost; 2) the eventually poorer harvesting quality, after taking into account the logging operation and its associated costs; and finally 3 ) at the opposite end of the scale, the costs of pre-harvest clearing. For example, Kärhä (2006) has determined that with a removal of industrial roundwood of $50 \mathrm{~m}^{3} / \mathrm{ha}$, a stem volume of 0.08 $\mathrm{m}^{3}$ and an average height of Norway spruce understorey of $2-3 \mathrm{~m}$, pre-harvest clearing will be a profitable operation for the whole economy whenever the density of the spruce understorey exceeds $1,400-2,800 \mathrm{stems} / \mathrm{ha}$.

In contrast, Heikkinen (2012) shows that the limits for pre-harvest clearing of Norway spruce understorey vegetation were 1,200 trees/ha, and the average height of this understorey was $4 \mathrm{~m}$, and, respectively 2,200 spruce understorey trees/ha with an average height of $3 \mathrm{~m}$. The corresponding pre-harvest clearing limit for broadleaved understorey vegetation was $5,000 \mathrm{stems} / \mathrm{ha}$ in the study by Heikkinen (2012).

The results from this study were used to construct preharvest clearing guidelines (Table 2). However, these guidelines should be used conscientiously because the study results were based on subjective knowledge, and should, therefore, be validated (and possibly adjusted) by long-term empirical follow-up data collection and analysis of the effect of understorey trees on the working efficiency of forest machine operators.

Table 2. The pre-harvest clearing guidelines for first thinnings at Stora Enso WSF drawn up based on the study results Understorey tree:

- All trees with a diameter over the bark at breast height $\left(\mathrm{d}_{1.3}\right)$ of less than $8 \mathrm{~cm}$.

Pre-harvest clearing limits:

- Logging sites, where there would be a lot of hindering understorey in cutting, are pre-cleared:

$\circ$ When logging first-thinning wood in summer, if the density of understorey vegetation, which is taller than 1.5 metres, is over 2,000 trees/ha.

- When logging first-thinning wood in winter, if the density of softwood understorey, which is taller than 1.5 metres, is over 2,000 trees/ha, or if the density of broadleaved understorey, which is taller than 1.5 metres, is over 4,000 trees/ha.

Implementation of pre-clearance:

- Pre-clearance is done in advance before logging during the period without thick snow cover on the ground.

- $\quad$ Trees eligible for logging are cleared within a circular area with a radius of one metre and the short $(<10 \mathrm{~cm})$ stumps are sawn (when pre-clearance is carried out during no snow cover, short stumps can be sawn).

- In intermediate areas (i.e., outside of circular areas), the understorey trees taller than 1.5 metres are pre-cleared.

- The logging area is completely pre-cleared along its borders.

No pre-clearance:

- Small depression areas as well as areas suitable for saving tree groups, and the shorelines of rivers and streams.

- $\quad$ Rare tree species, goat willows, woody European mountain ashes, common junipers (Juniperus communis L.), and willow bushes which are located more than one metre away from the butts of the trees to be pre-cleared.

- All forest sites mentioned in Section 10 of the Forest Act in Finland (Ministry of Agriculture and Forestry, 2014).

Range of the usage of pre-harvest clearing guidelines:

- All first-thinning stands, regardless of whether the logging site is harvested for industrial roundwood, energy wood, or both.

\section{Conclusions}

The study clarified the views of the different groups within the wood supply chain when the logging site has to be pre-cleared, and also clarified which characteristics describe good pre-harvest clearing in first-thinning stands. In particular, the study aimed to determine the pre-harvest clearing limits to first thinnings only, because the current national pre-harvest clearing guidelines (Äijälä et al., 2019) do not include any accurate numerical pre-clearance limits in Finland.

It is critical that we understand the views of the different groups within the logging operations related to understorey vegetation and pre-harvest clearing needs. When the understanding of the views of different groups is up-to-date and thorough, it is easier to find a compromise with which the different groups (i.e., forest 
machine operators, forest machine entrepreneurs and logging officers) can operate efficiently and sustainably in first-thinning forests. It is imperative that we avoid making unnecessary pre-harvest clearings, and to ensure that when the pre-harvest clearing is carried out, it is done with a very high standard so that the money invested in it is not wasted.

\section{References}

Äijälä, O., Koistinen, A., Sved, J., Vanhatalo, K., Väisänen, P. (Eds.), 2019. Metsänhoidon suositukset (Recommendations of good silviculture). Tapion julkaisuja. $252 \mathrm{p}$.

Bergström, D., Di Fulvio, F., Nuutinen, Y., 2016. Effect of Forest Structure on Operational Efficiency of a Bundle-Harvester System in Early Thinnings. Croatian Journal of Forest Engineering, 37(1):3749.

Dehlén, J., 2010. Mindre studie av en ny gallringsmetod i stamtät förstagallring av gran i södra Sverige (A brief study of a new thinning method in dense firstthinning of spruce in southern Sweden). Sveriges lantbruksuniversitet, Skogshushållning, Examensarbete $12.49 \mathrm{p}$.

Eriksson, A., Lindberg, A., 2010. Förröjning i förstagallring - vad kostar det och följer utförarna instruktionerna (Cleaning understorey trees in first thinning - what is the cost and do the contractors follow their directive)? Sveriges lantbruksuniversitet, Skogshushållning, Examensarbete 18. 45 p.

Finnish Forest Centre. 2019. Korjuujäljen tarkastusten tulokset vuodelta 2018 (Harvesting quality in thinning stands in Finland, 2018). https://www.metsakeskus.fi/sites/default/files/tiedote -liite-korjuujalki-tarkastukset.pdf (Accessed: 21 September 2019).

Frank, N., 2006. Underröjning i förstagallring (Cleaning of understorey trees before thinning). Sveriges lantbruksuniversitet, Institutionen för skogens produkter och marknader, Examensarbeten 64. 9 p.

Haavikko, H., Kärhä, K., Hourula, M., Palander, T., 2019. Attitudes of Small and Medium-Sized Enterprises towards Energy Efficiency in Wood Procurement: A Case Study of Stora Enso in Finland. Croatian Journal of Forest Engineering, 40(1):107123.

Hakkuukonetyömaan ennakkoraivaus (Pre-clearance of mechanized harvesting site). 2001. Metsätehon opas. $7 \mathrm{p}$.

Heikkinen, A., 2012. Ennakkoraivaustarpeiden määrittäminen ensiharvennuskohteilla Metsähallituksen Kuhmon metsätiimissä (Determining of pre-clearing needs at first thinning sites in Metsähallitus forestry team of Kuhmo). Bachelor's Thesis. North Karelia University of Applied Sciences. $45 \mathrm{p}$.

Hjelmqvist, R., 2016. Jämförelse av produktivitet och kostnader för drivningsarbetet vid två olika förröjningsnivåer i första gallring av konfliktbestånd
(Comparison of productivity and costs for harvesting and forwarding at two different preclearance levels in first thinning of conflict stands). Sveriges lantbruksuniversitet, Institutionen för Skogens Biomaterial och Teknologi, Arbetsrapport 17. $37 \mathrm{p}$.

Jonsson, F., 2015. Hur påverkar avlövad underväxt kvaliteten och drivningskostnaden i gallring (How does leafless undergrowth affect quality and logging costs in thinning)? Sveriges lantbruksuniversitet, Institutionen för skogliga biomaterial och teknologi, Arbetsrapport $8.46 \mathrm{p}$.

Kärhä, K., 2006. Effect of undergrowth on the harvesting of first-thinning wood. Forestry Studies, 45:101-117.

Kärhä, K., 2015. Towards better pre-clearance guideline of undergrowth in first thinnings: Case study of Stora Enso Wood Supply Finland. In: Kanzian, C., Erber, G., Kühmaier, M. (Eds.), Forest Engineering: "Making a positive contribution". Abstracts and Proceedings of the $48^{\text {th }}$ Symposium on Forest Mechanization, Linz, Austria 2015:63-67.

Kärhä, K., Keskinen, S., 2011. Ensiharvennukset metsäteollisuuden raaka-ainelähteenä 2000-luvulla (First thinnings as a raw material source of Finnish forest industries in the $21^{\text {st }}$ century). Metsätehon Tuloskalvosarja 2/2011.29 p.

Kärhä, K., Rönkkö, E., Gumse, S.-I., 2004. Productivity and cutting costs of thinning harvesters. International Journal of Forest Engineering, 15(2):43-56.

Kärhä, K., Keskinen, S., Liikkanen, R., Kallio, T., Lindroos, J., 2006. Ennakkoraivaus osana ensiharvennuspuun korjuuta (Undergrowth pre-clearance as a part of first-thinning wood harvesting). Metsätehon Raportti, 187. 77 p.

Korhonen, K.T., Ihalainen, A., Ahola, A., Heikkinen, J., Henttonen, H.M., Hotanen, J.-P., Nevalainen, S., Pitkänen, J., Strandström. M., Viiri, H., 2017. Suomen metsät 2009-2013 ja niiden kehitys 19212013 (Finnish forests 2009-2013 and their development in 1921-2013). Natural Resources Institute Finland, Natural resources and bioeconomy studies 59/2017. $86 \mathrm{p}$.

Lankinen, T., 2012. Uuden ennakkoraivausohjeen ja työvaikeusluokittelun käyttöönotto Metsä Groupin harvennuskohteilla (The new pre-clearance methods and the working difficulty guides introduced in Metsä Group thinnings). Bachelor's Thesis. HAMK University of Applied Sciences. 52 p.

Ministry of Agriculture and Forestry. 2014. Forest Act, $1093 / 1996$, amendments up to 567/2014 included. https://www.finlex.fi/fi/laki/kaannokset/1996/en199 61093.pdf (Accessed: 21 September 2019).

Ministry of Agriculture and Forestry. 2015. National Forest Strategy 2025. Government Resolution of 12 February 2015. Publications of the Ministry of Agriculture and Forestry 6b/2015. 56 p.

Natural Resources Institute Finland. 2019a. Hakkuukertymä ja puuston poistuma, Hakkuukertymä metsäkeskusalueittain (Roundwood removals and 
drain, Removals by forest center area). http://statdb.luke.fi/PXWeb/pxweb/fi/LUKE/LUKE 04\%20Metsa_02\%20Rakenne\%20ja\%20tuotant o_ 10\%20Hakkuukertyma\%20ja\%20puuston\%20po istuma/01_Hakkuukertyma.px/table/tableViewLayo ut1/?rxid=001bc7da-70f4-47c4-a6c2-c9100d8b50db (Accessed: 21 September 2019).

Natural Resources Institute Finland. 2019b. Metsänhoito- ja metsänparannustyöt, Hakkuupinta-alat (Silvicultural and forest improvement works, Cutting areas).

http://statdb.luke.fi/PXWeb/pxweb/fi/LUKE/LUKE 04\%20Metsa 02\%20Rakenne\%20ja\%20tuotant

o 12\%20Metsanhoito\%20ja\%20metsanparannusty ot/07_Hakkuupintaalat_mk.px/table/tableViewLayo ut1/?rxid=31895822-9689-4415-bacb-d9dd7dbdfb51 (Accessed: 21 September 2019).

Natural Resources Institute Finland. 2019c. Metsänhoito- ja metsänparannustyöt (Silvicultural and forest improvement works). http://statdb.luke.fi/PXWeb/pxweb/fi/LUKE/LUKE 04\%20Metsa 02\%20Rakenne\%20ja\%20tuotant o 12\%20Metsanhoito\%20ja\%20metsanparannusty ot/05 Metsanhoitojametsanparannustyot.px/table/tab leViewLayout1/?rxid=001bc7da-70f4-47c4-a6c2c9100d8b50db (Accessed: 21 September 2019).

Niemistö, P., Korpunen, H., Laurén, A., Salomäki, M., Uusitalo, J., 2012. Impact and productivity of harvesting while retaining young understory spruces in final cutting of downy birch. Silva Fennica, 46(1):81-97.

Oikari, M., Kärhä, K., Palander, T., Pajuoja, H., Ovaskainen, H., 2010. Analyzing the views of wood harvesting professionals related to the approaches for increasing the cost-efficiency of wood harvesting from young stands. Silva Fennica, 44(3):481-495.

Pålsson, M., 2013. Behovsgrad av förröjning i förstagallring av konfliktbestånd, avverkad med flerträdshantering (Required level of pre-commercial thinning in conflict stands, thinned with multistemming aggregate). Sveriges lantbruksuniversitet, Institutionen för sydsvensk skogsvetenskap, Examensarbete 206. 38 p.

Sanz, B., Malinen, J., Hujala, T., Tokola, T., 2019. ALSbased estimation of vegetation hindering cut-tolength harvesting operations. In: Berg, S., Talbot, B. (Eds.), Forest Operations in Response to Environmental Challenges. Proceedings of the Nordic-Baltic Conference on Operational Research (NB-NORD), June 3-5, 2019, Honne, Norway. NIBIO Book, 5(6):48.

Sjöqvist, M., Olofsson, V., 2018. Förröjningens påverkan på avverkning med förstagallringsskördare (Precleanings effects on first-thinning). Sveriges lantbruksuniversitet, Examensarbete 19.27 p.

Skogelid, O., 2019. Underväxtens påverkan på produktiviteten och gallringskvalitén hos två gallringsskördare (The impact of undergrowth on productivity and thinning quality for two thinning harvesters). Sveriges lantbruksuniversitet, Skogshushållning, Examensarbete 2. 32 p.

Strandström, M., 2018a. Timber harvesting and longdistance transportation of roundwood 2017. Mets $\ddot{a}$ tehon Tuloskalvosarja 7b/2018. 31 p.

Strandström, M., 2018b. Average harvesting conditions in Finland in 2017. Metsäteho Ltd, Unpublished statistics.

Thunell, A., 2008. Kvalitet och ekonomi i utförandet av förstagallring baserat på olika gallrings- och underväxtröjningsprogram (Quality and economy in first thinning based on different thinning and preclearance programs). Sveriges lantbruksuniversitet, Institutionen för skoglig resurshushållning, Arbetsrapport 218. 38 p. 